\title{
SURVIVAL IN TRAUMATIC TRANSVERSE MYELITIS
}

\author{
By Professor W. O. Geisler, M.D., Professor A. T. Jousse, M.D. and \\ MEgAN WynNe-Jones, M.D. \\ Lyndhurst Lodge Hospital, Department of Rehabilitation Medicine, \\ University of Toronto, Toronto, Canada
}

\begin{abstract}
Spinal cord injury resulting in paraplegia or tetraplegia has from time immemorial led to early death. Mortality figures as high as 80 per cent over a few years have been noted.

Following World War II as a consequence of the intensive care extended to these casualties, the mortality has been significantly diminished. The mortality has been studied on three occasions by the authors and two previous papers have been published, the first in I96I and the second in 1968.

The present paper is based on a mortality and longevity study which covers the period from I January 1945 to 30 November 1973, an interval of 29 years less one month. It deals with the mortality of spinal cord injured persons following treatment in Lyndhurst Lodge Hospital and reveals that there has been significant improvement over the period of study.
\end{abstract}

Key word: Transverse myelitis.

\section{Introduction}

THIS is a report of the third study conducted by the authors on the survival of persons who having suffered traumatic spinal cord lesions subsequently underwent rehabilitation treatment at Lyndhurst Lodge Hospital in Toronto, Canada. The period covered in this study is from I January I 945 to 30 November I973, an interval of 29 years, less I month. This includes the persons who were studied on the two previous occasions, the first of which dealt with the interval from I January 1945 to 3 I December I958 (Breithaupt et al., I96I) an interval of I4 years and the second from I January I945 to 3I December I966 (Jousse et al., I968) or 22 years. The numbers involved are for the first study, 599, for the second, 965, and for the third, I 50I. Not all were injured between I January I 945 and the closing date noted, for the majority of World War II injuries were incurred before the opening of Lyndhurst Lodge in January 1945. Also a few civilians injured prior to January I 945 were included, if treated at Lyndhurst Lodge. To be included, the casualty must have survived the first acute hospital admission and have been transferred to Lyndhurst for participation in the rehabilitation programme.

As more than 90 per cent of those treated at Lyndhurst Lodge have been discharged to their own domiciles in the community, this study reflects not only the efficacy of the education and treatment programme at Lyndhurst but as well the quality of ongoing medical care and supervision available in the community to which the man or woman returned. The large majority were residents of the Province of Ontario but a few took up residence in other Provinces of Canada. A very small proportion lived in the U.S.A., the British Isles, or on Continental Europe, some being from Iron Curtain States.

Intermittent catheterization was not performed on these persons.

The three studies have been sponsored by the Manufacturers Life Insurance 
Company. ${ }^{1}$ The objective has been to follow each individual to the last known address. For those who had died, the place and date of death was determined and, if known, the cause of death.

\section{Methodology}

The method of search was to direct a questionnaire to the last known address. One thousand, one hundred and twenty-six such were mailed or handed out with a reply being received from 7I7 (64 per cent). At the time of mailing 326 of the total of I 50I persons were known to be dead. Forty-nine were still under treatment and had not left hospital (Lyndhurst) for the first time. Two hundred and eightythree who did not reply to the questionnaire or were not otherwise contacted were traced through the Workmen's Compensation Board of Ontario, the Canadian Paraplegic Association, the Department of Veteran's Affairs of Canada, the Manufacturers Life Insurance Company or by means of phone calls to doctors and hospitals.

One hundred and two were reported as dead. This, in addition to the 326 known to be dead at the time the questionnaire was sent out. Twenty-four could not be located up until the end of November 1973. Four of this group were subsequently traced and found to be alive. However, they were not included in the study. Thus, 98.5 per cent of I 501 were identified and included in the report. Of the I 50 I, 428 or 26 per cent are known to be dead (Table I).

\section{Results}

Table I shows the mortality from all causes as it relates to the four diagnostic classifications of injured persons, namely, partial and complete, paraplegia and tetraplegia.

Percentage mortality was determined in comparison with that for the general population based on a normal standard rate for Iooo life years of exposure for comparable age-groups in the Canadian population. ${ }^{2}$

TABLE I

Mortality from traumatic transverse myelitis

\begin{tabular}{lccc}
\hline & Patients & Deaths & $\begin{array}{c}\text { Mortality } \\
\text { Expected }\end{array}$ \\
Partial paraplegia & 450 & II & I \\
Partial tetraplegia & 353 & 87 & 223 \\
Complete paraplegia & 484 & I53 & 464 \\
Complete tetraplegia & 214 & 69 & I I 63 \\
Total & I50I & 428 & \\
\hline
\end{tabular}

1 The statistical work was done by Mr D. Ross, B.Sc., under the direction of Mr J. L. Cummins, F.S.A., and Dr D. J. Breithaupt, Medical Vice-President. The Retail Credit Company (now Equifax) achieved follow-up on nine-tenths of those who did not answer the Lodge questionnaire.

2 The percentage mortality figures shown in the various tables are ratios of actual to expected mortality where the expected mortality is based on the I965-1967 Ontario population mortality as published by the Dominion Bureau of Statistics, catalogue No. 84527, January I97I. 
TABLE II

\begin{tabular}{lrc}
\hline Cause of death & Number of deaths & $\%$ of total deaths \\
\hline Renal failure & $\mathrm{I} 32$ & $30 \cdot 8$ \\
Cardiovascular disease & 87 & $20 \cdot 4$ \\
Respiratory & 52 & $\mathrm{I} 2 \cdot 2$ \\
Neoplasm & 42 & $9 \cdot 8$ \\
Cerebrovascular accident & 29 & $6 \cdot 8$ \\
Pressure sores & $\mathrm{I} 9$ & $4 \cdot 4$ \\
Suicide & $\mathrm{I} 8$ & $4 \cdot 2$ \\
Gastro-intestinal & $\mathrm{I} 8$ & $4 \cdot 2$ \\
Others & $\mathrm{I} 5$ & $3 \cdot 5$ \\
Accidental & 7 & $\mathrm{I} \cdot 6$ \\
Liver disease & 5 & $\mathrm{I} \cdot 2$ \\
Unknown & 4 & $0 \cdot 9$ \\
$\quad$ Total & 428 & $\mathrm{I} 200$ \\
\hline
\end{tabular}

\section{TABLE III}

Deaths

\begin{tabular}{lccc}
\hline & Autopsy & No autopsy & Unknown \\
\hline Partial paraplegics & 47 & 68 & 4 \\
Partial tetraplegics & 35 & 52 & $\mathbf{I}$ \\
Complete paraplegics & 76 & 75 & 2 \\
Complete tetraplegics & 28 & 40 & 0 \\
Total & I86 & 235 & 7 \\
& $43 \%$ of & $55 \%$ of & $2 \%$ of \\
& total & total & total \\
& deaths & deaths & deaths \\
\hline
\end{tabular}

The difficulty in assessing the risk for incomplete lesions is acknowledged for the impairment of function for this group ranges from negligible to profound and incapacitating. The mortality risk may vary accordingly. By contrast complete lesions provide a standard measurable degree of disablement for each level of injury and as a consequence the findings are more meaningful in this group.

Complete cord lesions are defined as such after careful and repeated neurological examinations over many months have revealed 'complete paralysis below the level of cord injury-complete loss of all modalities of sensation including anal and rectal sensation and complete visceral and sphincteric paralysis' (Botterell et al., 1975). Incomplete lesions by contrast manifest impairment of motor and sensory function to any extent short of total abolition.

For the 428 persons who have died Table II shows the cause of death attributed in 409 instances. Four are unknown and 15 are grouped as 'others'. The percent- 
age of total is shown in the right-hand column for each cause. Causes of death are not divided into the two categories used by Tribe et al. (1969) namely related to paraplegia and unrelated to paraplegia. This is so because it has never been clear to the authors just what causes are in fact related to paraplegia. Indeed, one of the purposes of this study is to determine any possible relationship existing between causes of death and transverse myelitis other than the established relationship for renal failure and decubiti.

The determination of the cause of death was supported by autopsy in 43 per cent of cases (Table III). No autopsy was performed in 235 instances or 55 per cent of the total deaths and for seven cases or 2 per cent it is not known if an autopsy was performed.

In Tables IV to IX comparison is made between death in transverse myelitis and the leading causes of death in our general population which are cardiovascular disease, cancer, respiratory disease, accidents and suicide.

Table IV, containing all partial lesions, has been divided into two age-groups for statistical purposes. The ages selected are 20-44 (24 years) and 45-64 (I9 years) ${ }^{1}$

\section{TABLE IV}

Total of partial lesions

\begin{tabular}{|c|c|c|c|}
\hline Cause of death & & No. of deaths & $\begin{array}{l}\text { Expected in } 197 \text { I } \\
\text { Canadian population }\end{array}$ \\
\hline \multicolumn{4}{|l|}{ Age-group 20-44 } \\
\hline Accidents & 5 & & 5 \\
\hline Cardiovascular disease & 8 & bladder (I) & 2 \\
\hline Cancer & 42 & $\begin{array}{l}\text { brain (I) } \\
\text { bowel (I) } \\
\text { general (I) }\end{array}$ & I \\
\hline Suicide & 3 & & I \\
\hline \multicolumn{4}{|l|}{ Age-group 45-64 } \\
\hline Cardiovascular disease & $2 \mathrm{I}$ & $\begin{array}{l}\text { lung (4) } \\
\text { bowel (3) } \\
\text { larynx (3) } \\
\text { stomach (2) }\end{array}$ & 20 \\
\hline Cancer & I7 & $\begin{array}{l}\text { skeletal (I) } \\
\text { prostatic (I) } \\
\text { mouth (I) } \\
\text { Hodgkins (I) } \\
\text { general (I) }\end{array}$ & 9 \\
\hline Accidents & - & & 2 \\
\hline Respiratory & 12 & & I \\
\hline Suicide & 5 & & I \\
\hline
\end{tabular}

1 'Leading causes of death by sex in various age groups \#5.45, page 226 Canada Year Book 1973.' 
Excepting accidental deaths, which are unchanged, the overall totals reveal increased mortality for the major causes of death. In cardiovascular disease, this increase is noted only in the younger age-group and for respiratory disease only in the older age-group. Suicide and cancer are increased in both age categories.

The unavoidable lack of homogeneity of data entering into the three studies, in addition to the small number of deaths reported in many of the tables where the results have been analyzed by cause of death and age, means that the results must be interpreted with caution. This is especially true where less than four deaths are reported in any category.

\section{TABLE V}

Total of complete lesions

\begin{tabular}{|c|c|c|}
\hline Cause of death & No. of deaths & $\begin{array}{l}\text { Expected in I97I } \\
\text { Canadian population }\end{array}$ \\
\hline \multicolumn{3}{|l|}{ Age-group 20-44 } \\
\hline Accidents & 2 & 4 \\
\hline Cardiovascular disease & I I (bladder (3)) & 2 \\
\hline Cancer & $5\left\{\begin{array}{l}\text { lung (I) } \\
\text { general (I) }\end{array}\right.$ & I \\
\hline Suicide & 8 & I \\
\hline \multicolumn{3}{|l|}{ Age-group $45-64$} \\
\hline Cardiovascular disease & I5 (bladder (2) & I I \\
\hline Cancer & $4\left\{\begin{array}{l}\text { breast }(\mathrm{I}) \\
\text { bowel (I) }\end{array}\right.$ & 5 \\
\hline Accidents & - & 20 \\
\hline Suicide & I & 0.6 \\
\hline
\end{tabular}

Table $\mathrm{V}$ contains all complete lesions and reveals similar findings to those for partial lesions for the younger age-group. It must be borne in mind that this study is based on persons who have survived the early acute care and entered on the rehabilitation phase.

Tables IV and V reveal significantly increased mortality for cardiovascular disease and cancer. There may be some association with renal disease for the former. The increased incidence of cancer is related to a variety of sites and appears not to affect any specific organ. All tetraplegics are particularly at risk from respiratory disease. Where respiratory death is increased the early deaths from this cause known to approach 50 per cent of total deaths are not included.

It will be recalled that partial lesions constitute a group whose members may experience disablement ranging from minor to major incapacity. Nevertheless, there is a significant increase in deaths from cardiovascular disease and cancer for the younger age-group in this classification. 


\section{TABLE VI}

Total of partial paraplegia

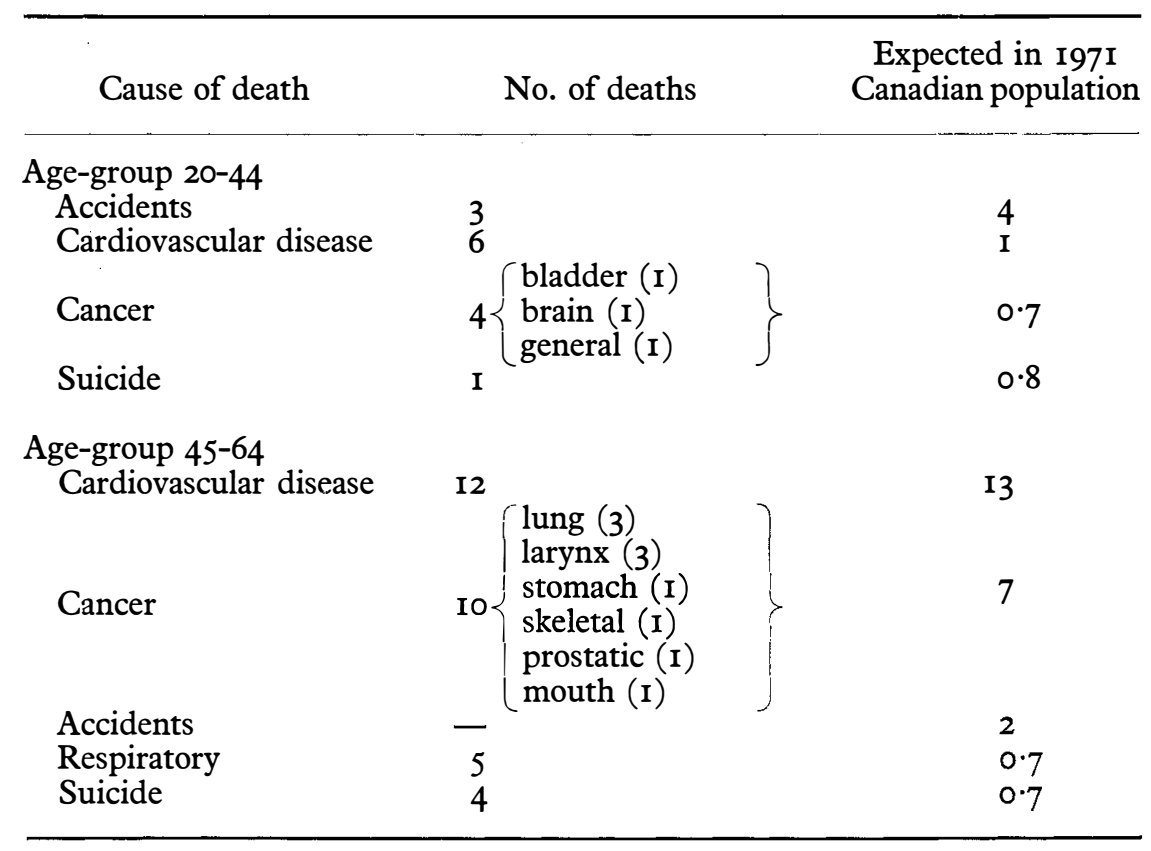

In the older age-group there is a significant increase in respiratory deaths and suicide (Table VI).

Table VII suggests a trend toward greater mortality for cardiovascular disease and suicide for the younger age-group. However, one must not consider this as significant on the basis of the few involved.

The older age-group reveals a significant increase for respiratory deaths and cancer. The increase for cardiovascular disease is of questionable significance.

In Table VIII a significant increase in mortality from cardiovascular disease, cancer and suicide is shown for the younger group. The 45-64 year group mortality from cardiovascular disease is again of questionable significance.

Table IX reveals a significantly increased mortality from cardiovascular disease in the younger group.

Table X shows by decades the age of onset of traumatic transverse myelitis. The well-known peak (Jousse, unpublished, Kraus et al.) occurring in the third decade is repeated. Nevertheless, almost as many occur after age 30 (717) as before (784).

It is thus seen to be a disorder which strikes many in the prime of life when physical resources are maximal and personal adaptability most flexible. The majority of victims may reasonably expect many years of survival. Hence measures of prevention must needs be sought diligently together with betterment of rehabilitation for those who become disabled.

Table XI reveals the causes of mortality by decades omitting the first. Renal failure remains at the top of the list by a wide margin to the end of the eighth 


\section{TABLE VII}

Total of partial tetraplegia

\begin{tabular}{|c|c|c|}
\hline Cause of death & No. of deaths & $\begin{array}{l}\text { Expected in I97I } \\
\text { Canadian population }\end{array}$ \\
\hline \multicolumn{3}{|l|}{ Age-group 20-44 } \\
\hline Accidents & 2 & 2 \\
\hline Cardiovascular disease & 2 & 0.8 \\
\hline Cancer & - & 0.5 \\
\hline Suicide & 2 & 0.5 \\
\hline \multicolumn{3}{|l|}{ Age-group $45-64$} \\
\hline Cardiovascular disease & $9\left\{\begin{array}{l}\text { bowel }(3) \\
\text { general }(\mathrm{I})\end{array}\right.$ & 6 \\
\hline Cancer & $7\left\{\begin{array}{l}\text { lung }(\mathrm{I}) \\
\text { stomach }(\mathrm{I}) \\
\text { Hodgkins }(\mathrm{I})\end{array}\right.$ & 3 \\
\hline Accidents & 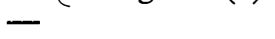 & 0.8 \\
\hline Respiratory & 7 & 0.3 \\
\hline Suicide & I & 0.3 \\
\hline
\end{tabular}

TABLE VIII

Total of complete paraplegics

\begin{tabular}{|c|c|c|}
\hline Cause of death & No. of deaths & $\begin{array}{l}\text { Expected in } 197 \mathrm{I} \\
\text { Canadian population }\end{array}$ \\
\hline \multicolumn{3}{|l|}{ Age-group 20-44 } \\
\hline Accidents & I & 3 \\
\hline Cardiovascular disease & 4 & I \\
\hline Cancer & $4\left\{\begin{array}{l}\text { bladder (3) } \\
\text { general (I) }\end{array}\right.$ & $0 \cdot 8$ \\
\hline Suicide & 6 & I \\
\hline \multicolumn{3}{|l|}{ Age-group 45-64 } \\
\hline Cardiovascular disease & ${ }^{\text {I3 }}$ (bladder (2) & 9 \\
\hline Cancer & $4\left\{\begin{array}{l}\text { breast (I) } \\
\text { bowel (I) }\end{array}\right.$ & 4 \\
\hline Accidents & - & I \\
\hline Respiratory & - & 0.5 \\
\hline Suicide & $\mathbf{I}$ & - \\
\hline
\end{tabular}


TABLE IX

Total of complete tetraplegia

\begin{tabular}{lcc}
\hline \multicolumn{1}{c}{ Cause of death } & No. of deaths & $\begin{array}{c}\text { Expected in I97I } \\
\text { Canadian population }\end{array}$ \\
\hline $\begin{array}{l}\text { Age-group 20-44 } \\
\text { Accidents }\end{array}$ & I & I \\
Cardiovascular disease & 7 & $0 \cdot 6$ \\
Cancer & I lung (I) & $0 \cdot 3$ \\
Suicide & 2 & $0 \cdot 3$ \\
Age-group 45-64 & & \\
Cardiovascular disease & 2 & 2 \\
Cancer & - & I \\
Accidents & - & $0 \cdot 2$ \\
Respiratory & - & I \\
Suicide & - & $0 \cdot I$ \\
\hline
\end{tabular}

TABLE X

Age of onset of spinal cord injury

\begin{tabular}{lrrrrrrrr}
\hline & O-9 & IO-I9 & $20-29$ & $30-39$ & $40-49$ & $50-59$ & $60-69$ & $70-79$ \\
\hline Partial paraplegia & 7 & 4 I & I63 & 96 & 7 I & 46 & 24 & 2 \\
Partial tetraplegia & 3 & 7 I & IOI & 53 & 4 I & 52 & 30 & 2 \\
Complete paraplegia & 7 & 64 & I92 & II 8 & 63 & 28 & 9 & 3 \\
Complete tetraplegia & I & 48 & 86 & 40 & 22 & I4 & I & 2 \\
$\quad$ Total & I8 & 224 & 542 & 307 & I97 & I40 & 64 & 9 \\
\hline
\end{tabular}

decade. The increased deaths due to cardiovascular disease, respiratory disease, suicide and neoplasms are significant. The highest incidence of suicide falls in the fifth decade whereas the highest incidence of onset of traumatic transverse myelitis is in the third decade. This suggests that suicide is not necessarily an impulsive act during the first depressive phase but is frequently a carefully considered act.

Table XII presents the female deaths by type of lesion. It reveals a trend towards a more favourable mortality rate for the female than the male as is noted in the general population. Thus, although constituting 13.2 per cent of the total patients, but 10.8 per cent of the total deaths occurred in females. 
TABLE XI

Primary cause of death by age-groups

\begin{tabular}{|c|c|c|c|c|c|c|c|c|}
\hline & IO-I9 & $20-29$ & $30-39$ & $40-49$ & $50-59$ & $60-69$ & $70-79$ & Over 79 \\
\hline Renal failure & 2 & 24 & 22 & 23 & 29 & I8 & IO & 4 \\
\hline Cardiovascular & - & 2 & 9 & 14 & I6 & 27 & IO & 9 \\
\hline Respiratory & I & 5 & 7 & 6 & 17 & 8 & 6 & 2 \\
\hline \multicolumn{9}{|l|}{ Cerebrovascular } \\
\hline & - & - & 4 & 5 & 7 & II & 2 & 一 \\
\hline Suicide & - & 2 & 3 & 9 & 2 & I & I & - \\
\hline Gastro-intestinal & - & 3 & 3 & 4 & 3 & 2 & I & 2 \\
\hline Pressure sores & - & 5 & 2 & 4 & 4 & 2 & 2 & - \\
\hline Liver disease & - & - & 3 & I & - & I & - & - \\
\hline Neoplasm & - & - & 6 & 4 & 8 & I9 & 4 & I \\
\hline Unknown & - & - & - & I & 2 & I & - & - \\
\hline Others & - & 2 & 4 & 5 & 2 & I & I & - \\
\hline Accidental & - & 2 & 3 & 2 & - & - & - & - \\
\hline
\end{tabular}

TABLE XII

Female deaths

\begin{tabular}{lcc}
\hline & Patients & Deaths \\
\hline Partial paraplegia & 46 & 7 \\
Partial tetraplegia & 42 & I0 \\
Complete paraplegia & 82 & I7 \\
Complete tetraplegia & 28 & I2 \\
Total & 198 & 46 \\
& 13.2\% of & I0. $8 \%$ of \\
& total patients & total deaths \\
\hline
\end{tabular}

\section{Discussion}

It has long been known that the mortality in traumatic spinal cord casualties is very high during the first weeks or months following onset with a peak death rate during the first 2 weeks (Botterell et al., 1975). Indeed prior to World War II this mortality trend continued until all but a few sturdy survivors numbering io to 20 per cent of the total lived beyond a Io-year period. It is therefore of interest to learn the mortality when the first Io-year period of exposure is omitted. Table XIII provides this information through comparison with Table I. 
In this table the mortality has been determined for exposure after Io years, that is from Io to 20 years or until the time of death or the present date (1973) if survival exceeds Io years. Comparison with Table I results (right-hand column) reveals improvement in mortality in all four categories, most marked for complete tetraplegic casualties. Many of the spinal injured casualties have now been exposed for three decades and a few are into the fourth.

In the early post World War II period it was recognized from our first study that the mortality rate had been markedly altered and 80 per cent or more survived for longer than 20 years. Indeed our total mortality is now only 26 per cent.

In order to make a comparison of mortality over two approximately equal periods of time Table XIV has been prepared. The total interval of 29 years has been divided into two periods, January I945 to December 1958 and January 1959 to November 1973 .

The mortality rate (actual over expected) for these two periods reveals a significant betterment for the latter period in the last three categories. The increased mortality from I959 to I973 in the first category suggests that only more severely involved incomplete paraplegics were referred to Lyndhurst in the latter I 5-year period as compared with the earlier period.

In Table XV a comparison is made between our three studies. The bracketed figures represent the ratio of actual deaths to expected deaths as determined in our first study terminating in I958 and published in I96I using the then current mortality figures. In the first column headed I960, the mortality

\section{TABLE XIII}

Percentage mortality (after Io years' exposure)

\begin{tabular}{lccc}
\hline & Deaths & $\%$ mortality & $\begin{array}{c}\text { Table I } \\
\% \text { mortality }\end{array}$ \\
\hline Partial paraplegia & 70 & I 58 & I8I \\
Partial tetraplegia & 29 & 2 I6 & 223 \\
Complete paraplegia & 86 & 443 & 464 \\
Complete tetraplegia & $2 \mathrm{I}$ & $85 \mathrm{I}$ & $\mathrm{I} 63$ \\
\hline
\end{tabular}

\section{TABLE XIV}

Actual/expected mortality ( $\%$ )

\begin{tabular}{|c|c|c|}
\hline & Jan. I945-Dec. I958 & Jan. I959-Dec. I973 \\
\hline Partial paraplegia & (I0 deaths) $\quad 135 \%$ & (20 deaths) \\
\hline Partial tetraplegia & (20 deaths) $\quad 480 \%$ & (22 deaths) $\quad 202 \%$ \\
\hline Complete paraplegia & (24 deaths) $568 \%$ & (2I deaths) $301 \%$ \\
\hline Complete tetraplegia & (I4 deaths) I $487 \%$ & (25 deaths) II $40 \%$ \\
\hline
\end{tabular}




\section{TABLE XV}

Actual/expected mortality: a comparison of three studies

\begin{tabular}{lrrr}
\hline & I960* & I968 & I973 \\
\hline Partial paraplegia (I39) & I95\% & II $8 \%$ & I8I \% \\
Partial tetraplegia (220) & $308 \%$ & $216 \%$ & $223 \%$ \\
Complete paraplegia (475) & $665 \%$ & $400 \%$ & $464 \%$ \\
Complete tetraplegia (I256) & I758\% & I200\% & I I63\% \\
\hline
\end{tabular}

* These mortality percentages have been adjusted by the factor $I \cdot 4$ for the difference in the mortality tables used in the I960 study published in $196 \mathrm{I}$.

\section{TABLE XVI}

Expectation of life (in yr) for partial and complete para- and tetraplegics

\begin{tabular}{|c|c|c|c|}
\hline Age & 1960 & 1968 & 1973 \\
\hline \multicolumn{4}{|c|}{ A. Partial paraplegics } \\
\hline 20 & $42 \mathrm{yr}$ & $45 \mathrm{yr}$ & $42 \mathrm{yr}$ \\
\hline 30 & $34 \mathrm{yr}$ & $36 \mathrm{yr}$ & $34 \mathrm{yr}$ \\
\hline 40 & $25 \mathrm{yr}$ & $28 \mathrm{yr}$ & $25 \mathrm{yr}$ \\
\hline 50 & $18 \mathrm{yr}$ & $22 \mathrm{yr}$ & I8 $\mathrm{yr}$ \\
\hline \multicolumn{4}{|c|}{ B. Partial tetraplegics } \\
\hline 20 & $3^{8} \mathrm{yr}$ & $4 \mathrm{I} \mathrm{yr}$ & $4 \mathrm{I} \mathrm{yr}$ \\
\hline 30 & $30 \mathrm{yr}$ & $32 \mathrm{yr}$ & $32 \mathrm{yr}$ \\
\hline 40 & $22 \mathrm{yr}$ & $24 \mathrm{yr}$ & $24 \mathrm{yr}$ \\
\hline 50 & $\mathrm{I} 4 \mathrm{yr}$ & $16 \mathrm{yr}$ & $16 \mathrm{yr}$ \\
\hline \multicolumn{4}{|c|}{ C. Complete paraplegics } \\
\hline 20 & $27 \mathrm{yr}^{1}$ & $34 \mathrm{yr}$ & $32 \mathrm{yr}$ \\
\hline 30 & $20 \mathrm{yr}$ & $27 \mathrm{yr}$ & $25 \mathrm{yr}$ \\
\hline 40 & I4 $\mathrm{yr}$ & $19 \mathrm{yr}$ & I9 $\mathrm{yr}$ \\
\hline 50 & $8 \mathrm{yr}$ & $12 \mathrm{yr}$ & $12 \mathrm{yr}$ \\
\hline \multicolumn{4}{|c|}{ D. Complete tetraplegics } \\
\hline 20 & $15^{\star} \mathrm{yr}$ & $2 \mathrm{I} \mathrm{yr}$ & $2 \mathrm{I} \mathrm{yr}$ \\
\hline 30 & $\mathrm{II}^{\star} \mathrm{yr}$ & I6 yr & I $6 \mathrm{yr}$ \\
\hline 40 & $7^{\star} \mathrm{yr}$ & IO yr & Io $\mathrm{yr}$ \\
\hline 50 & $3^{\star} \mathrm{yr}$ & $5 \mathrm{yr}$ & $5 \mathrm{yr}$ \\
\hline
\end{tabular}

* These mortality percentages have been adjusted to reflect the difference in the mortality tables used in the I960 study. 
percentages have been adjusted by the factor $\mathrm{I} \cdot 4$ to bring them into line with the later studies. It must be borne in mind that the two last studies include all the persons previously reported upon. There has been no improvement in mortality between I966 and I973. In fact mortality may have increased.

Table XVIA compares the life expectation for partial paraplegia at ages 20 , 30, 40 and 50 years for the three studies. At all ages the I 968 study reveals improvement and equally portrayed is the decline in the I973 study which may well be a consequence of the fact that we are dealing at Lyndhurst with the more severely disabled incomplete lesions.

For partial tetraplegia, Table XVIB reveals a solid gain of 2 years or more between I 960 and I968 which is retained but not bettered in the I973 study.

Table XVIC shows the results for complete paraplegia. Very substantial gains were made between 1960 and I968, that is of 7 years for ages 20 and 30, of 5 for the 40-year age-group and 4 for the 50-year age-group. The I 973 results show no improvement over 1968 and for 20 and 30 years a slight drop.

The gains for complete tetraplegia between I960 and I968 are convincing and are maintained but not bettered in our I973 study. The overall gains are substantial (Table XVID).

\section{Discussion}

In this third study of mortality in traumatic transverse myelitis we have been able to gather information on a significantly larger number of individuals than in our earlier studies. It is particularly significant that whereas the first study included relatively few tetraplegics, as very few survived their first hospital admission, this third study involves a significant number. Of equal importance to the validity of the study is the high percentage of the total group traced and identified.

From our first study we were able to confirm the clinical impression that significant improvement in mortality had taken place in the decade following World War II. From the second we learned that further improvement had been achieved though it was much less dramatic. From the third study, that no demonstrable improvement has been achieved during the past decade and indeed in certain categories we appear to have lost ground.

The causes of death reveal the same pattern in all three studies with renal failure remaining the leading cause though its percentage position is now lower. This reflects improved treatment of urological complications. As well longer survival exposes casualties to the degenerative diseases of later life.

The comparison with the leading causes of death in our society reveals that these subjects are particularly vulnerable to respiratory disease, cancer, suicide and cardiovascular disease. The latter cause appears to have moved up in the younger age-group which may be related to the widespread kidney involvement known to exist.

The diverse sites in which cancer appears in these persons is puzzling but a pattern may develop when larger groups are studied in the future.

It is most important that a similar actuarial type of study be carried out from centres practising intermittent catheterization for a similar period of time. Only in this way will it be possible to make a valid comparison with our cases. One would hope that such a study may reveal marked betterment in mortality from renal disease and perhaps from cardiovascular disease. Above all one would hope for an improvement in the quality of life through lessening of morbidity. 


\section{RÉSUMÉ}

Les lésions du cordon médullaire qui ont pour résultat la paraplégie ou la tétraplégie ont de toute éternité occasionné une mort prématurée. La statistique révèle une mortalité, au cours de quelques années, de jusqu'à $80 \%$.

Après la guerre mondiale II, resultant des soins intensifs donnés à ces accidents, la mortalité a été très réduite-d'une manière significative. La mortalité a été étudiée trois fois par les auteurs et deux écrits antérieurs ont été publiés, l'un en I96I et le second en I968.

Cet écrit est basé sur une étude de la mortalité et de la longévité qui comprend la période depuis janvier I, I945, jusqu'à novembre 30, I973, une intervalle de 29 ans, moins un mois. Il traite de la mortalité des sinistres de lésion du cordon médullaire après traitement médical dans Lyndhurst Lodge Hospital. Il fait resortir une amélioration significative au cours de la période de l'étude.

\section{ZUSAMMENFASSUNG}

Verletzungen des Rückenmarks hinauslaufend auf Paraplegie und Tetraplegie ist immerwährend die Ursache des frühzeitigen Tod gewesen. Sterblichkeitziffer bis auf $80 \%$ wurden während einiger Jahre aufgedekt.

Nach dem Weltkrieg II, folgend der intensiven Pflege dieser Patienten, ist die Sterblichkeit bedeutend vermindert. Die Verfasser haben dreimal die Sterblichkeit studiert und zwei vorhergehende Arbeiten wurden veröffentlicht; die erste in Jahre 196I, die zweite im Jahre I968.

Diese These ist auf einer Untersuchung der Sterblichkeit und der Langlebigkeit gregründet; sie fast zusammen die Periode von Januar I I945 bis November I973, eine Zwischenzeit von 29 Jahre minus ein Monat. Sie behandelt die Sterblichkeit der Patienten mit Verletzungen des Rückenmarks folgend der Behandlung in Lyndhurst Lodge Hospital, und zeigt eine bedeutende Verbesserung während der Periode der Behandlung.

\section{REFERENCES}

Botterell, E. H., Jousse, A. T., Kraus, A. S., Thompson, M. G., Wynne-Jones, M. \& Geisler, W. O. (1975). Annals of the Royal College of Physicians and Surgeons of Canada, July I975, Footnote, p. I94.

Breithaupt, D. J., Jousse, A. T. \& Wynne-Jones, M. (1961). Canadian Medical Association Fournal, No. 85, 73-77, July 8.

Jousse, A. T., unpublished.

Jousse, A. T., WynNe-Jones, M. \& Breithaupt, D. J. (1968). Canadian Medical Association fournal, No. 98, 770-772, April 20.

KraUS, J. F. (1974). Prepublication preliminary draft. Incidence of Traumatic Spinal Cord Lesions.

Tribe, C. R. \& Silver, J. R. (1969). Renal Failure in Paraplegia. Pitman Medical Publishing Company Limited, London.

\section{General Discussion}

Dr Gregory (U.S.A.). Could you explain the arithmetic? I don't understand I35 per cent or 480 per cent. What is that a percent of?

DR A. Jousse (Canada). It is the percentage ratio of the number of paraplegics who died in comparison with the general population actuarialy determined. If rooo people were exposed for so many years, it's usually on an annual basis, a 1000 people from the general population statisticians know at age $20,30,40$ or 50 how many will die, they don't know which ones will die but they know how many will die in a year. They compare that figure with the actual deaths recorded by paraplegics per thousand per year, for the same age-group. It's a statistical device that the insurance people use to determine expectation of life for insurance purposes.

DR GREGORY. I'm still puzzled over the high percentages. I thought that is 50 per 
cent higher mortality or 20 per cent higher or something, not 138 per cent. That sounds strange.

DR A. JoussE. Mortality in complete tetraplegia is about 12 times the normal; that's where the I200 per cent is. And for complete paraplegia about 400 per cent, and for partial paraplegia about I75 per cent, and incomplete paraplegia is $125-135$ per cent; something like that.

DR H. J. M. BARNeT (Chairman). It must be gratifying to those who had the vision, as Sir Ludwig Guttmann did in Britain and Dr Harry Botterell did in Canada, to set up these paraplegic units to see these survival rates. I wonder, Dr Botterell, if you'd like to make any comment at this point. I just happened to see you there. Any other comments or questions about Dr Jousse's paper.

DR J. BourRet (France). We saw a relatively high incidence of suicides amongst mortality. My question is were the cases of primary attempts of suicide excluded from your whole number of your patients or were they included.

DR Jousse. What was that again, Sir?

DR JACQUES BOURRET. We saw in the late mortality, a high incidence of suicide. Now my question: Were among your I500 patients the cases of primary suicidal attempts excluded or included? The causes of the primary paraplegia?

DR JoussE. We couldn't determine that really. I think we only knew of about two people who became paraplegic having attempted suicide by shooting themselves and admitting it afterwards. They were not included excepting one of them who subsequently after he became paraplegic lived for a number of years and did commit suicide successfully; he was included, one of them was not included.

Chairman. Any other questions. Thank you very much, Dr Jousse.

International Congress on Cleft Palate

Third International Congress on Cleft Palate, 5 to Io June 1977 inclusive, Toronto, Canada. 